Robinson, Madrice H. Organizing a Business. Pp. vi, 269. Price, $\$ 2.00$. Chicago: LaSalle Extension University, 1915.

This book deals primarily with the corporation inasmuch as more than half its pages treat that subject. Dr. Robinson tells what a corporation is and how it is formed; the main features of charters and by-laws; the rights and obligations of bondholders, stockholders and creditors; and the number, names and duties of officers. The leading forms used in corporate management are set forth in minute detail and at great length.

In addition to the corporation, the author devotes a small fraction of his space to other forms of organization; for example, three pages-constituting one chapter-are given over to a discussion of the advantages and disadvantages of Individual Proprietorship, and another chapter similarly concise, treats the subject of Partnership. Business combinations and Trusts and the comparative efficiency of various types of organization are also touched upon.

Since Dr. Robinson did not see fit to preface his work with a statement of his purposes, we must base our opinion of the object he hoped to attain from the text itself. We would think the work was intended for a treatise on business law if it were not for the fact that the series of which this work constitutes one nember, already contains two volumes under the title Business Law, so we suspect that Organizing a Business was intended for the guidance of (very) young men living in rural communities, and about to enter business for the first time.

We must admit, however, that the book has an attractive cover.

R. M. K.

\title{
MONEY, BANKING AND FINANCE
}

Prato, Giuseppe. Documenti Finanziari degli Stati della Monarchia. Pp. xiii, 315. Price, L. 20. Torino: Societa Tipografico, 1916.

\section{SOCIOLOGY AND SOCIAL PROBLEMS}

Bar, Carl Ludwig von. A History of Continental Criminal Law. Pp. Ivi, 561. Price, \$4.00. Boston: Little, Brown and Company, 1916.

The science of Criminology cannot stop with a study of crime and the criminal. Criminal law and procedure as well as penology must be considered. In the reconstruction now going on in these fields new light must be sought from historical sources in order to avoid the repetition of error on the one hand and to determine methods of effectiveness on the other. Hence the value of such historical study as von Bar has made in his History of Continental Criminal Law. Roman and Germanic sources are particularly rich in their influence on later codes. After a study of these sources, the author adds chapters dealing with France before the revolution, Scandinavia, Switzerland and The Netherlands. Then follows several chapters dealing with the period of the French Revolution and the changes produced in France, Germany and other countries. A division of the work is devoted to the modern period comprising chiefly the nineteenth century. The last division, Part II, comprises a history of the theories of criminal law. "To disentangle and trace all the aspects and details of modern criminal 
law in their development amidst the congeries of law, morals, religion and custom in successive past epochs, is a huge and delicate task, which might well make the boldest historian halt." This task the author has performed so well that his work will be invaluable not only to students of the subject but to practical legislators who seek to draft codes that will remedy some of the glaring defects of American criminal procedure.

\section{University of Pennsylvania.}

J. P. LichtenBerger.

Bigham, J. A. (Ed. by). Select Discussions of Race Problems: A Collection of Papers of Especial Use in Study of Negro American Problems, with the Proceedings of the Twentieth Annual Conference for Study of Negro Problems held at Atlanta University, May 24, 1915. Pp. 108. Price, 50 cents. Atlanta: The Atlanta University Press, 1916.

Bonger, Wirliam Adrian. Criminality and Economic Conditions. (Trans. by Henry P. Orton.) Pp. xxix, 706. Price, \$5.50. Boston: Little, Brown and Company, 1916.

The author of this volume is probably correct in the assumption that the English-speaking countries have been influenced greatly by the work of the Italian School of Criminology and that the hereditary aspects of the subject have been overemphasized, but he is mistaken, we think, in his further assumption that his ideas about the ethology of crime will be unwelcomed by American scholars. On the contrary, any rational theory of causation appeals to the American mind and this masterful presentation of the economic factors of criminality will be accepted as a most valuable complement to the factors stressed by the Italian School. That which will be called in question is the contention that economic factors alone are sufficient to explain the phenomenon of crime. This the author does more by implication than by definite statement. With due allowance for this predisposition, no work has appeared in English of greater value in a generation. Beginning with a description and criticism of the various groups of writers which he designates as the Precursors, the Statisticians, the Italian and French Schools, the Bio-Socialists, the Spiritualists, etc., the author proceeds to his own explanation of the causes of crime which are inherent in our present Economic System. By a wealth of statistics and an analysis of social causes including a study of sex and the family, etc., he has in a most convincing manner revealed the effects of environment in producing crime. Elements neglected or slighted by previous authors are given their proper significance. The American Institute of Criminal Law and Criminology has rendered an invaluable service to the science of criminology by placing this book before the English-reading world. It ought to stand on the shelf beside Lombroso, Garofalo and Aschaffenberg in every collection of criminological literature in the country.

University of Pennsylvania.

J. P. Lichtenbergen. 